\title{
DEMOGRAPHY OF WAR AND METHODS FOR CALCULATING THE LOSS OF LIFE
}

\author{
Milena PALCZEWSKA, PhD \\ War Studies University \\ Military Faculty
}

\begin{abstract}
This study analyses the relationship between war and population. The impact of the growth and decline of population on important types of warfare - armed conflicts and classic war. At its root, the importance of the link between demography and war is the relative capacity of a given political unit's population to aid in its defense or to threaten other political units. For this reason, population increase and decrease have always been identified as vital security issues. Demography and war will continue to be an important and policy-relevant topic.
\end{abstract}

Key words: war, armed conflicts, demography.

\section{Demographic theory of war}

Genesis of demographic theory of war is to be seen until ancient times, as it should be derived from the views of Heraclitus of Ephesus, Stasinos from Cyprus and Plato. These representatives of the ancient philosophical thought have argued that excessive population growth, in particular, uncontrolled by the state, while not keeping up with producing consumer goods, especially food, leads to wars, above all aggressive wars. For example, Plato argued that owner of the land will not be able to always feed the excessive number of its inhabitants, which very often leads to the concept of broadening it, at the expense of a neighboring country, and this in turn is the most common cause of wars. Therefore, Plato, supported the idea of birth control, but made in an automatic way by the people who feared that excessive population growth, will be a cause of poverty and war. Such conviction was the basis to develop a comprehensive demographic theory of war.

The main thesis of the demographic theory of war is the assertion that the fundamental driving force of history is the demographic factor, so the birthrate and population density. This theory is based on the conviction that demographic factors, that is population, influence of development of society, but also the formation of wars. According to this theory, the main cause of the war is connected with the contradictions between population growth and the ability to ensure adequate minimum means of subsistence for the rapidly growing population.

The demographic theory of war, the most widespread version of it, was developed by Thomas Malthus, and is sometimes called his name as Malthusian theory. T. Malthus predicted that population, in the absence of external constraints, doubles its size in 25 years, 
$5^{\text {th }}$ International Conference on Research in

and the number is growing exponentially. ,Population - in the absence of obstacles - is increasing exponentially. Livelihoods increases only in arithmetical progression. Even small knowledge of arithmetic is sufficient to establish unprecedented strength of the first agent in relation to the other. This causes the existence of the constant obstacles population growth, leaving the difficulty of living. This difficulty must arise and must, according to necessity, be sharply sensed by a large part of humanity”. ",The imbalance between population growth (geometric progression) and the increase of living (according to an arithmetic progression) could be limited, according to Malthus, and even offset only by the constant action of harsh laws which need obstacle to force higher order"2. It is the strength of a higher order, that is, war or armed conflict, is the only force that can maintain a balanced population growth and livelihoods.

According to T. Malthus, the main source of war, is identified with the disproportion between rapid population growth and remaining behind, a quantitative increase in food production. War, according to T. Malthus, can play a significant role of the regulator, limiting the rapid population growth. However, it called on the conscious and deliberate organization of war, or to not oppose to epidemics or natural disasters, because he considered them to be a huge disaster for mankind. Nevertheless, they constitute a lesser evil than the prospect of the total disaster of mankind. In addition, T. Malthus proves that ,there are two main causes of wars. Firstly, population pressure and poverty are the most serious causes of wars. Secondly, the war solve the problem of population pressure and poverty, because during the war killed a large part of the population"3.

War have a huge impact on all areas of the development of social life, and especially on the population. The impact of war on the population in a demographic sense, can be analyzed from different points of view. First of all, this impact can be studied in terms of quantity, that is from the point of view of determining the size of loss of life, borne by the population during the war. This is the most important and basic part of the task of studying the effect of war on the population. At the same time it should be emphasized that the change in the number of population is closely linked to changes in the population structure, as a result of the war because the structure of the population by sex and age and family composition are changed significantly. The war has also had a great influence on the indicators of physical development, the ability of people to work (disability). The war also affects the level of incidence - the spread of the epidemic is often associated with the conduct of the war, changing the mode of life of the population. One cannot emphasize moreover, the impact of war on the cultural level of the population: literacy rates, the degree of coverage of children and youth teaching in schools - all of this is directly related to the general situation of the country during the state of war.

\footnotetext{
${ }^{1}$ T. Malthus, Prawo ludności, De Agostini Poland, Warsaw 2003, p. 69.

${ }^{2}$ L. Wyszczelski, Teorie wojenne i ich twórcy na przestrzeni dziejów, Wydawnictwo Neriton, Warsaw 2009, p. 169.

${ }^{3}$ Ibidem, p. 172.
} 
$5^{\text {th }}$ International Conference on Research in

The demographic theory of war and peace is an integral part of the general theory of the development of society bearing the name of the demographic development theory of society. The main idea of this theory is the assertion that the fundamental driving force of history is the demographic factor, i.e. increase and population density. It should be emphasized that the direction of the population is not homogeneous. There are in it, generally speaking two varieties. The first of them believe that the higher the population density, and the higher birth rate, the faster the development of society. The second one says that rapid population growth is inhibiting factor in the historical process. A population factor accelerates historical development only if there is no overcrowding. In the case of the latter it comes to social antagonisms, revolutions and wars. So the theory of demographic factors in population translates not only the development of society, but also wars and social revolutions. Therefore, it seems only fair to call it a trend of demographic theory of war and peace.

By demographic theory of war and peace we understand view, which says that the source of wars and social revolutions should be traced in the demographic factor, more precisely - in the growth and population density. In other words, the demographic theory is the opinion that the main cause of war lies in the contradiction between population growth and the provision of the rapidly growing population of the respective minimum livelihood. Proponents of this view are against representatives of the biological theory of war, affirmative that the genesis of the war lies in the nature of the human psyche, the alleged fighting instincts. Opposed to the ethical concepts which discharges need to wars with the spirit of the historic rights, the rights of absolute spirit.

With the adoption of the principle that the mainspring of the formation of all wars is vigorously developing natural growth, according to consistently evaluate and wars role in social development. This evaluation is as follows: wars are a necessary evil conditioned inevitably laws of nature, laws of demography. They are great misfortune for mankind, every man wants to live. This is one side of the issue. Second - organically linked with the first emphasizes the ethical moment. It is expressed in the fact that wars are allegedly necessary prophylactic agent, a natural instrument for security of mankind as a whole, from the disasters of a higher order - the biological death of the human species, which threaten her because of overpopulation. Only as a result ,,regulating” role of nature (war) society avoids this tragic consequences.

It is customary to think that the first issue of the wars in close liaison with the demographic factor has occurred only in T. Malthus. Historical research, however, refutes this assertion. Already in ancient thinkers we can find demographic interpretation of the origins of the war. Of course, the scale of interest in this problem was in ancient times much smaller than in the modern period. This is due to the difference of demographic relations day ancient and modern. We also cannot in any case be carried out of the equation sign between considerations of Plato and Aristotle and ideas of Malthus and his successors. Ancient philosophers not blamed nature responsible for the formation of wars, but see their causes in the society. While Malthus suggested that wars are a manifestation of purposeful activity of 
$5^{\text {th }}$ International Conference on Research in

nature, which thus wants to prevent overpopulation. To trace, even fragmented, the development of the theory of demographic wars, as well as highlight the difference between the views of ancient and malthusianism on this issue, we should briefly discuss the concepts of the ancient.

The first mention of the interdependence between the war and the overcrowding found in works Stasinos from Cyprus. It attempts to explain the causes of the Trojan War. Opposed to the traditional version of interpreting the genesis of this war, the kidnapping of the beautiful Helen. He argues that the reasons were entirely different. These reasons can be called a demographic reasons - population. He understands by wandering Greek tribes, caused by overcrowding. These tribes, grows rapidly numerically, set off to conquer other lands. In search of that they clashed with Trojans. Later thinkers of the era of ancient knew the original thought Stasinos from Cyprus, reject it or alluded to it. One of them was Plato, who although does not mention anywhere of his predecessor when considering this problem in the State and the Laws, but the thought had an impact on his views. Plato assumes the possibility, and at the same time the necessity of wars with its neighbors by its aristocratic ideal state, led by philosophers. The necessity of this derives from the socio-economic conditions. His ideal state as the natural increase will be forced to expand their territories to provide food to the citizens. Initially, residents perfect republic are very cautious and prescient, which is expressed mainly in the regulation of birth. This limitation is dictated first of all - the need to prevent excessive grinding agricultural estates and crafts, and secondly - it has effectively counteract overpopulation, which leads to wars. These people do not multiply ,,children over the state - Plato writes - because they were afraid of poverty or war" ${ }^{\prime 4}$.

However, over time among the inhabitants of the ideal state is born gradually dissatisfaction with what they have and want to have something more than nature gives them their own country. This discontent, at the same time the desire for something new, mainly due to the excessive population growth causing difficulties in the diet of all citizens of the state. And the earth, which then was enough to feed the inhabitants, will be too small. The reason for the additional, albeit less important than the first, will be the population of the state by people ,unnecessary", who make him only worries and all sorts of difficulties. These people „expendable”, eg. artists. They do not care about the welfare state, with its strength and vitality, but they have in mind, according to Plato, only to meet their own needs. Added to this is also the desire luxury, which not only undermines the moral health of individuals, but also the strength of the state. In this way withdrawing from the strict rules regulating births, the emergence of the country ,unnecessary" citizens and continuing more forward growth needs not necessary lead to a situation in which the only way out is war with its neighbors. Plato writes: ,and then from the land of neighbors, something we cut off the falls, if we have enough on its pastures and the plow, and at that (other countries) once again our land will be

\footnotetext{
${ }^{4}$ Platon, Państwo, Warsaw 1948, p. 100.
} 
$5^{\text {th }}$ International Conference on Research in

needed if they can be let go to make money without limits, and exceed the limit of what is necessary"5.

So social processes, leading to wars due to excessive population growth and growing needs, will also take place in a different city-states bordering the Platonic republic. This raises the disparity between the limited acreage of land and excessive density of people living in the territory of the state. In a similar position is a pupil, Plato, Aristotle. He represents the view that the people of the state should be strictly determined by the possibility of sustenance. Therefore, it is suggested that the Greek state called policies, should not exceed 10000 citizens. Any increase this number must cause, says Aristotle, the need to acquire new lands by the state, which in turn will lead to war.

The views Stasionus of Cyprus, Plato and Aristotle developed in later times other thinkers, but now from a different position. They pointed rather to the fact that with the development of society, the demand for means of material existence of man, on that basis and are born fierce rivalry between countries. Also they stressed the increase ,material desires" and luxury. Thus, for example Cicero sees the most important causes of war in the unbridled lust of man. The more people, the desires are greater. On the other hand, in the Middle Ages in the centuries of domination and religious philosophy - the demographic theory of war was not their representatives. Scholastic philosophers have explained the phenomenon of war to interference factor of the supernatural, prefer providence.

It was only in the eighteenth century a growing interest in the demographic problem and its impact on the fate of humanity, including the emergence of wars. This interest is conditioned by the action of new demographic laws, radically different from the kind of operating rights in previous eras. The emergence of capitalist relations of production, advancing more and more forward the industrial revolution, increasing labor supply, as well as the impoverishment of the working masses - all this evokes interest among scholars of demographic factors. They put forward the thesis that the rapid growth of natural causes impoverishment of the population, especially the population of backward countries in economic terms. At the same time they discussed the methods and ways to prevent the phenomenon of overpopulation. Therefore, in the circle of their interests was the war. We sought to determine whether there is a link between the outbreak of wars and relatively rapid population growth, and the role played war as a necessary evil in human development. In other words, if the war is one of the preventive measures against excessive reproduction of the population. The answer to these questions tried to give the English clergyman - Thomas Malthus.

T. Malthus is looking for regularities governing population growth. He is convinced that knowledge of these regularities, as well as understanding the consequences of rapid population will force nations to consciously limit the number of births. At the same time governments, where the population is growing relatively quickly, will be able to take

\footnotetext{
${ }^{5}$ Ibidem.
} 
$5^{\text {th }}$ International Conference on Research in

preventive measures aimed at significant inhibition of the number of births. Malthus believed that natural population growth does not take place by chance, but according to certain regularity. This pattern is allegedly geometric progression applied to the demographic development, more specifically the development of natural humanity carried out according to the principles of geometrical progression. The population in the absence of obstacles increases exponentially. Livelihoods increases only in arithmetical progression.

From the above demographic right, Malthus draws pessimistic conclusions. The disproportion between the rapid increase in population and a much slower development of the means of subsistence may, in his opinion, lead society to a catastrophe. It is therefore necessary to ensure a certain balance between the two factors: demographic and economic. The first one should be by all means limited „stringent laws of necessity”. This postulate Malthus concluded in the following words: ,force of population growth is the strength of higher order, because population growth can be kept in balance to the growth of the means of subsistence only thanks to the constant action of harsh laws which need obstacle to force higher order". That ,strength of higher order" lowers the standard of living, work intensification, poverty and disease, dependency layers poorer than richer ones, etc. To avoid progressing more and more impoverishment of society should apply preventive measures to counteract the excessive growth of the population. Author of Law of Population therefore calls layers of poor and middle-income to ,,abstinence" in the begetting of children, it is recommended marriages at a later age, etc.

Conscious activity of society is one preventive measure. The main measure is a regulating effect on wildlife behavior relative balance between rapid population growth and the development of material existence of society. Here and nowhere else, lies precisely the basis of theoretical and philosophical malthusian assessment of the role of war in human development. Malthus assumes that population growth is done according to the geometric rules only if it does not haunt humanity natural disasters, by which is meant primarily phenomena such as intermittent or chronic hunger, epidemics, natural disasters and war. These disasters, including war, are in Malthus all the hallmarks of a necessary evil. They are the result of imperative need arising from the need to ensure a balance between the state of the population and the state of the means of subsistence. It is natural, says Malthus, it creates a real obstacle laws of population, care for it, to prevent the catastrophe of humanity, causing wars, epidemics, natural disasters, etc. Malthus, however, not called to deliberate, conscious organizing wars, not to resist epidemics and natural disasters. He believed that these disasters are a great misfortune for the human species, but prevent even greater evil - the total disaster of mankind. War is, according to Malthus, phenomena, which nature uses only as a last resort. They cannot be completely avoided, but can be reduced by conscious human activity (birth control).

So, Malthus says that the source of war lies in the imbalance between the rapid growth of natural and remaining far behind the growth of food. Insufficient latter causes difficulties in

${ }^{6}$ T. Malthus, Prawo ludności, Jirafa Roja, Warsaw 2007, p. 25. 
$5^{\text {th }}$ International Conference on Research in

the diet of people, and hence - leads to a social nature, resulting in a reduction in the population. This process takes place with a natural necessity, resulting from the postulate of balance and a proper balance between population growth and the material conditions of existence, if this has not been ensured by other means. If society does not knowingly reduce growth, make this ,treatment” nature itself. Such assumptions are malthusian concept which is a variation of the demographic theory of war and peace.

There are many allegations that the Malthus's demographic theory of war is wrong. One of the arguments is the thesis that if the population multiplies exponentially globe would have to count around 60 billion people (at the time of Malthus earth had approx. 800 million inhabitants, doubling the cycle a population every 25 years will receive approximately the number of 60 billion people for the current year). Recent statistics indicate, however, that our planet is inhabited by over 7.2 billion people. As for this kind of calculation supporters of Malthus thesis put forward a reservation that does not take into account the effects of natural disasters, famines, wars, etc. But it is easy to justify that mentioned above „natural obstacles” could not make so great havoc in the birth rate, causing a loss of more than fifty billion human beings. The whole history of human society proves that it was never too many people in the world, that was not so absolute overpopulation. Negation of geometric ,right" of natural growth does not mean the negation of the rapid population growth that is taking place in recent times. This is confirmed by statistics compiled, as well as numerous publications demographers and economists, who try to predict population growth in the coming years ${ }^{7}$.

French demographer-economist, Alfred Sauvy, examined the issues of population, arguing that the rapid progress of medicine, ahead of economic progress will result in a drastic increase in the population, up to 170 billion by the year $2200^{8}$. In his view, the land is not able to feed the population. He says that all governments, as well as the whole society should be against the imminent danger of overpopulation immediately take appropriate preventive measures. He believes that the solution to this problem can be made five ways:

1. Inhibition of medical advances, so increase the mortality of people. But this measure is highly unethical.

2. Conscious, deliberate unleashing wars and social upheavals. War fought with weapons of mass destruction seriously reduce the number of inhabitants, and thus lead to a significant inhibition of birth. This road, like the previous one, however, is amoral and anti-humanist.

3. Large-scale emigration and immigration from overpopulated areas to sparsely populated areas and deserts. This possibility is real, but very expensive. This difficulty is further compounded by the boundaries of nation states.

4. The maximum development of all means of production and the use of any production capacity of the Earth.

5. Way of conscious birth.

\footnotetext{
${ }^{7}$ Example can be a publication of the Central Statistical Office Prognoza ludności na lata 2014-2050.

${ }^{8}$ A. Sauvy, Od Malthusa po Mao Tse-Tunga, Paris 1960, p. 76.
} 
$5^{\text {th }}$ International Conference on Research in

Behavioral and Social Science

Spain | Barcelona | December 7-9, 2018

The provided information also shows indirectly that the so-called natural obstacles to the development of mankind - epidemics, famine, natural disasters and war - are by no means a necessary evil, they are not a result ,,purposeful activity of nature". All the so-called natural obstacles have their profound social background. For example, at the root of hunger in India lie primarily source of a social nature, the nature of the relations of production and the dependence of long-lived people of India from British colonizers. Demographic factors are not decisive in the development of society, but not without influence on its course. They can accelerate this development or delay. High population density and rapid population growth in the conditions of system of operating type eg. in India intensified the misery of the people, but they were not the source of wars.

War is a social phenomenon and its causes are not in the nature, but in social relations. War, so to determine, no signs of nature in so far as society itself is a natural and social. In any event, there is the result of purposeful activity imaginary nature. Since war is the continuation of politics, and this, in turn, concentrated expression of economics, is it just, not in nature, not overpopulation should look for sources of wars. Acceptance of the theory that the cause of wars is over-population, has consistently lead to the conclusion that the war will take place as long as there will be public.

\section{Methods for calculating the loss of life}

War exert great influence on the dynamics of the size and structure of the population: increasing mortality, declining parity and population growth, reducing the number of concluded marriages. How to determine the loss the most accurate and correctly? What methods should at the same time become the basis of research? There is probably no other area of science in which there were such a divergence of data that exists in the statistics on the loss of life incurred during the war. Not only in time of war, but afterwards it publishes the most contradictory figures for war losses. Given eg. the number one source of losses incurred by Belgium and Serbia during World War I, nearly twenty times higher than the number of losses given in another source ${ }^{9}$. Given such a disparity of numbers researcher must use different methods to achieve maximum approximation to reality. First of all, to establish a community of people to be covered by the research. The entire population in the war should be divided into two categories: military and civilian. To include military officers and men of all types of weapons, located at the front, in reserve, on the back, in hospitals and on leave. In addition to the military include members of the guerrilla. All the rest are civilians.

To determine all of conscripts in the military sometimes we can use the term „,mobilized population". This term, however, is very useful. Firstly, civilian population can be mobilized during the war to perform functions of a military nature (eg. earthmoving, construction of various fortifications). Secondly, part of the army is composed of volunteers who are not mobilized. An example of this is France, where during the war in 1914-1918

\footnotetext{
${ }^{9}$ Wider: B. Urłanis, Wojny a zaludnienie Europy, Państwowe Wydawnictwo Ekonomiczne, Warsaw 1962.
} 
$5^{\text {th }}$ International Conference on Research in

Behavioral and Social Science

Spain | Barcelona | December 7-9, 2018

participated 229 thousand French volunteers and 40 thousand foreign volunteers. In the Spanish civil war of 1936-1939, it fought on the Republican side of 35 thousand volunteers from 54 countries ${ }^{10}$.

Some researchers in the calculation of war losses avoided at all of the division of the population on military and civilian, using the concept of direct and indirect losses. Frequently when determining losses it is considered all the losses among the military as direct, and the losses among the civilian population - as an intermediate. But this is completely wrong. Direct losses, ie. the direct cause of the conduct of the war, may arise among both military and civilian. It is known that as a result of air raids during World War II killed more than 1 million people from the civilian population. Even during World War I were killed by air raids approx. 5 thousand civilians ${ }^{11}$. The delimitation of the military from the civilian population, however, is only a first step to determine the number of war casualties. The next step in the research is to classify the losses among the military according to the types of losses. Should be very carefully delimited losses in the demographic sense of loss in terms of military operations. From the point of view of demographic losses in the military must pass all deaths, regardless of their origin (wounds, diseases etc.). With military-operational point of view, the loss is usually considered not only the deaths of soldiers and officers, but all kinds of leaving the ranks, even temporarily. Therefore, the military-operational point of view, the loss except for the dead - also includes captured, disappeared without a trace, as well as the wounded and sick, admitted to hospitals.

In terms of military operation is often used term ,,irreversible loss”, extending it killed died due to various reasons, disappeared without a trace and taken prisoners. In some cases, irreparable loss determined the total number of people who had left the ranks, adding to the number of killed, dead and captured - including soldiers and officers, who as a result of wounds or diseases were released from the army. Also used the term „loss of blood”, which includes a number of dead and wounded, including the wounded and those who got the captivity. All these concepts of losses are important from the point of view of militaryoperating, because they give an idea of their own and the enemy's military reserves. In order to assess the result of the military operation we need to know about how much the state decreased in numbers army, regardless of whether the soldiers who gone from the ranks during the battle, and if they will return later to the front or not. From the point of view of human casualties result of hostilities shall be determined taking into account not only the number of killed, but the total number of soldiers who - at least temporarily - are out of the ranks of the army. In some calculations, it is expedient determination of losses including the return of part of the wounded to the ranks. With this account the total number of dead and wounded is reduced by the number of wounded who after recovery returned to the ranks.

\footnotetext{
${ }^{10}$ Wider: J. Farndon, Historia świata: 2000 rzeczy, które musisz wiedzieć, Podsiedlik-Raniowski i Spółka, Poznań 2001.

${ }^{11}$ Civilian death from air bombardment, Statistical Bulletin Metropolitan Life Ins. Co.
} 
$5^{\text {th }}$ International Conference on Research in

Let us dwell on the classification of the loss of life of these types of losses from the point of view of military-operational. Typically, the losses incurred as a result of military operations are served with an additional division for the dead, the wounded and injured, prisoners and disappeared without a trace. To the latter category they belong all the soldiers and officers, which the fate of the military authorities do not have any messages. This group usually includes those fallen soldiers and officers whose death has not been established or who were captured in unknown circumstances. The share of this questionable group (missing without a trace) in the overall sizes of the losses depends largely on the nature and outcome of the war. The army offensive dispose of much more accurate data about their losses of war and participation ,disappeared without a trace" will be in this case smaller. With backflow while the group is growing significantly, as retreating army cannot always keep entire system records. In fact, most of the retreating army ,,disappeared without a trace" are those who were captured.

In the literature we can sometimes find out with a different understanding of the same categories of losses. One example is the sharing of all types of losses in addition to the irreversible (they are killed, captured, missing without a trace) and sanitation, which include the wounded and injured. In this division should not be opposed irretrievable sanitary losses, some losses because sanitation is also irretrievable. In addition, this classification does not include the loss of basic sanitation categories such losses, namely - the sick. Losses sanitary divided into combat (wounds, injuries, frostbite, burns etc.) and non-combat (disease, trauma).

Combat losses opposes sometimes sanitary losses. The balance of the combat losses includes all the fallen, missing without a trace, captured, badly wounded and dismissed from the service, and the loss of sanitation - all the wounded and sick. It is difficult to agree with such division. Why wounded, who left the hospital as disabled, they get a group of combat losses, and are not counted among the wounded, who cure even in hospitals, although both the one and the others were wounded during the war? More specifically, the loss of sanitation should be included only those that are actually related to the activities of military health institutions. From this point of view, all cases of hospitalization, wounded, injured, thawed, burns should be treated as sanitation losses. There is also the notion „fatal loss of health”, which include all deaths from diseases and injuries, if the patients were in the military sanitary facility or any other therapeutics facility. This notion of loss of health is important for overall assessment of the military medical service. The term ,,sanitation losses" can be understood also in a much narrower sense, taking into account only the losses due to diseases.

Table 1 presents the classification of war losses. It distinguishes two main groups of losses - combat and non-combat. Each of them is divided into two types of losses: irreversible and temporary. 
$5^{\text {th }}$ International Conference on Research in

Behavioral and Social Science

Spain | Barcelona | December 7-9, 2018

Table 1. Classification of war losses

\begin{tabular}{|c|c|c|c|}
\hline \multicolumn{2}{|c|}{ Combat } & \multicolumn{2}{|c|}{ Non-combat } \\
\hline irreversible & temporary & irreversible & temporary \\
\hline $\begin{array}{l}\text { The fallen (died before } \\
\text { granting medical aid) }\end{array}$ & Wounded & Died from diseases & Patients \\
\hline Missing without a trace & Injured & $\begin{array}{l}\text { Died as a result of non- } \\
\text { combat injuries }\end{array}$ & $\begin{array}{l}\text { Exemptions holiday (to } \\
\text { reserve) due to illness }\end{array}$ \\
\hline Captured & Frostbite & $\begin{array}{l}\text { Died as a result of } \\
\text { suicide }\end{array}$ & \\
\hline $\begin{array}{l}\text { Died on the way to the } \\
\text { first medical point } \\
\text { (wounded and injured } \\
\text { in the fighting) }\end{array}$ & Burned & $\begin{array}{l}\text { Dismissed due to } \\
\text { illness } \\
\text { injuries) }\end{array}$ & \\
\hline $\begin{array}{l}\text { Died in captivity } \\
\text { Died of wounds in } \\
\text { treatment plants }\end{array}$ & $\begin{array}{l}\text { Other injuries } \\
\text { sustained in battle (gas } \\
\text { poisoning etc.) } \\
\text { Exemptions holiday (to } \\
\text { reserve) as a result of } \\
\text { injuries sustained In } \\
\text { the fight }\end{array}$ & & \\
\hline $\begin{array}{l}\text { Dead from other causes } \\
\text { related to the fight } \\
\text { Dismissed from army } \\
\text { due to wounds and } \\
\text { injuries }\end{array}$ & & & \\
\hline
\end{tabular}

B. Urłanis, Wojny a zaludnienie Europy, Warsaw 1962, p. 19.

With a number of the points listed in the table we cannot do anything else but agree. First of all, it allows a double bill. Group ,died in captivity” enter eg. at the same time the group ,,captured". Dismissed from the army as the disabled are also covered by the number of wounded and sick. In addition, the group ,,missing without a trace" should not be regarded as irreversible losses, but a part ,disappeared without a trace”, finds itself because after some time. There should also be counted death in captivity to combat losses. The mere fact of getting into slavery is a result of war, but not all of the consequences of this fact considered as combat losses. With this approach, almost every death in the military during the war, to a greater or lesser extent, is related to the conduct of military operations, so there would be almost no non-combat losses.

Another type of classification is a classification of losses in the demographic sense. It must be emphasized that the wounded and sick prisoners who have recovered, and those who returned from captivity, are listed in this or any other section or time irreversible losses in reporting military operations cease, however, they are counted in the category of losses from the point of view of demography. Speaking about the losses in the demographic sense we 
$5^{\text {th }}$ International Conference on Research in

mean military deaths from all sorts of reasons. While the offices of military invalid discharged from military service is irretrievably lost, that from a demographic point of view, cases of disability are not considered to be a loss, because the life of a soldier was preserved. Category of losses in the demographic sense, however, requires classification. At first plan there is a reason for the loss. The cause may be a direct result of combat operations, or may not be directly associated with them. Consequently, all the losses should be divided into combat and non-combat. On the other hand, in the context of combat losses must extract the dead and the dead from wounds. To the dead are counted, all died in the battle, in individual skirmishes, during the attack, during reconnaissance operations and in general, all died in the war. It should also include all the soldiers and sailors who died at sea because their death is usually directly related to the conduct of military operations.

In particular, we should stay on the category of the dead from wounds. As a result of combat death of a soldier or officer may not be instantaneous, but take place some time after the wound respect, however this period varies widely. Depending on the length of time that the death of soldiers and officers noted in various sections statistics. The category of the fallen in battle include not only cases of immediate death, and death on the battlefield; it also includes the dead in a few hours after the reference wounds, for example when soldier dies as a result of blood loss, not having received medical attention at the time. He died of his wounds, but since it was not known or did not appear in any documents, all such cases are recorded under the heading, ,killed in battle”. Only the fate of those wounded who were in the military records of the sanitary service, it may be traced statistically and all the fatal consequences of injuries in this category may be covered by the term ,died of wounds".

We can see that it is difficult to perform a strict border between the fallen and dead from wounds. The problem arises of whether the dead should be included in all the dead soon after the reference mortal wound. In the German military statistics in the nineteenth century attempted to solve this problem using the criterion specified number of hours that a soldier or officer survived the respect wounds. When determining the number of soldiers of the Prussian army who died in the war Austro-Prussian assumed eg. in the statistics of military criterion 48 hours of life on the reference mortal wound. All the wounded who survived 48 hours and died before the end of the year, they were numbered among the dead from wounds. When calculating the losses in the Franco-Prussian border between the fallen and the dead from the wounds it was determined according to the criterion; they fell and died within 24 hours after the battle. In such a manner, everyone who died from the wounds within the first day after the battle had been classified in the group of killed ${ }^{12}$.

The US military health statistics for the dead from wounds during World War II place all the soldiers and officers who died after showing them first aid. Those who were still alive after the battle, but died before the giving of the first aid had been classified in the group of died, as well as those who died immediately ${ }^{13}$. From what we mentioned earlier, it follows

\footnotetext{
${ }^{12}$ Zeitschrift des Königlich Preussischen Statistischen Landesamts, tom 11, number 1-4, p. 268.

${ }^{13}$ G. Beebe, M. de Backey, Battle Casualties, Springfield 1952, p. 9.
} 
$5^{\text {th }}$ International Conference on Research in

that, the percentage of the dead from wounds affects not only the adoption of a particular critical for completing the fallen in war for this or that group, but also the level of military medical service. If injured are taken from the battlefield later, the number of fatally injured is in the category of the fallen and the proportion of the injured died of wounds is significantly reduced. This clearly shows that the percentage of the dead from the wounds may be an indicator of the quality of work of the medical service only if we keep the same speed of withdrawal of the wounded to hospitals. Increased transport of wounded - at the same other conditions - leads to an increase in the share of severely injured and as a consequence - increase the percentage of the dead from wounds.

Besides a fast enough taken wounded from the battlefield, a great impact on the level of mortality due to injuries are transport conditions. In the old wars the conditions of transport of wounded to hospitals were so bad that much of the injured died on the way. In addition, the group of died of wounds include generally any deaths in the sanitary treatment facilities as a result of burns, frostbite or injury. Non-combat losses include, first of all the deaths of soldiers and officers as a result of diseases in hospitals, military hospitals and other inpatient settings, the second - all cases of emergency, immediate deaths among the military outside hospitals. The group of non-combat losses we must extract the category of soldiers and officers who died of non-combat injuries (if they have been recognized in non-combat conditions), as a result of suicides and murders, executed by the judgments of courts and tribunals field of war. A separate group includes all deaths in captivity, in particular as a result of starvation and disease. Strictly speaking, the death in captivity of wounds received in battle should be included in the loss of combat. But that was not fully correct, since many of the wounded died in captivity from wounds, most likely should be saved from death in hospital of their own army. Their death is not so much a result of wounds, but the result of being in captivity.

Let us note also the category ,,missing without a trace". This category of loss can exist only in time of war, when we cannot determine the cause of the diminution of the ranks. After the war, category ,missing without a trace” should be replaced by the heading ,missing without a trace, not yet traced down". With the passage of time since the end of the war, this section decreases gradually explained because the fate of missing soldiers and officers. After a sufficiently long period of time, all covered by category ,not yet traced down" should be numbered among the dead, if there is no reason to believe that at stake migration processes.

However, it should be noted, that not all of the losses incurred during the war are the result of the war. Of course, even if there were a war in a few years a part of the members of the army have died also, being a civilian. The life of every man, even at a young age and in times of peace, contains a certain risk of death. It should exclude such deaths, to receive the amount of losses resulting from the war. Therefore, speaking about war casualties, to distinguish between two concepts: global losses, ie. the total actual number of military dead in the war, and the loss of clean, the size of which is obtained after deduction of normal (under the circumstances) mortality. It is this size makes it possible to determine the extent of 
$5^{\text {th }}$ International Conference on Research in

irreversible losses be fully attributed to the war. In determining the size of irreversible losses of life incurred as a result of wars, great help may be material to the census. This is especially valuable when the census was made shortly before the war and after the war. For if the list was made in a long time after the war, on the results of influence not only factors related to the war, but also occurring in the postwar period.

Materials related to the population of a country in general are extremely valuable from the standpoint of study on the impact of war on the population. In these materials, however, are shown not only the losses among soldiers but also among civilians. From the point of view of the sociology of war may be a much more interesting materials census broken down by gender. These materials can be used in two ways: first, by comparing the data only on the number of men and, second, by comparing the data on the number of men and women. The first issue that will be discussed is the problem of using data on the number of men. It is not difficult to understand that a simple comparison of census data from the pre-war post-war census data does not have any idea about the casualties resulting from the war. It allows only set as long decline in the number of males in the period between censuses. To get the size of the loss of men, to be next to the actual numbers, according to census data postwar calculate the hypothetical number, ie. to determine if the male population would be in the country on the post-war census, if there were no war. The difference between the number of hypothetical and actual corresponds to the size of the defect numbers of men, formed as a result of the war. However, due to the war, the loss of male arises not only due to the death suffered in the war, but as a result of declining birth rate in general, and boys in particular, higher male mortality among the civilian population and so on. Therefore, the determination of war losses among the military on the basis of the above data is not possible.

Arose as a result of war, the loss of population can be divided into four essential elements: 1) soldiers and officers killed and died in the war; 2) the civilian population died as a direct result of the war (bombing, military operations, terror etc.) and indirect impacts of war (increased mortality due to malnutrition, hunger, epidemics, etc.). 3) reducing the number of children due to the decrease in diversity during the war; 4) The difference between the number of people coming to the country and the number of people who have left the country. For more accurate data on irretrievable losses among the military service, taking as a basis the data about the number of men with regard to the grouping by age. We can still make the following statement: determine how many men certain vintages and how many there should be a given day, if there were no war. In other words, we should compare the actual census data with hypothetical calculation data, relating to the same age group. The difference between them can be considered as pure losses incurred as a result of the war.

Another area of use of census materials is the so-called calculation of women predomination, by which we mean the number of female superiority over the number of men. The size of the advantages are often considered to be the equivalent of the number of soldiers and officers killed or died in the war. Such treatment ,women predomination”, however can often lead to significant errors in the calculation. When analyzing ,women predomination” 
$5^{\text {th }}$ International Conference on Research in

should therefore be necessary to take into account a number of factors and circumstances. First of all, the comparison should be done not for the entire population of the country, but only in relation to specific age groups. If the census was conducted just after the war, it must take into account the age of 18-49 years, and if such was made. 5 years after the war, we have to take into account the population aged 23-54 years. And it should not be limited to the post-war census. The advantage of the number of women over the number of men could also exist before the war. Therefore, we need to manipulate the data pre-war census of the population structure according to sex, on the same age groups. Only the difference between the two ,,predomination" in the number of women may give some material to the assessment of the loss of the men in the war. If, for example, we assume that for 8 years before the war was in a country 300 thousand more women than men, aged 8-39 years, and if after the war lasted suppose 2 years (ie. after 10 years) were in the same country 1500 thousand more women than men, aged 18-49 years, then subtracting 300 thousand from 1500 thousand, we get the number of 1200 thousand. This particular number can give a rough idea of the size of losses among the military. With this kind of comparison must, however, take into account more the following three very important circumstances.

First - migration processes. It is known that among the emigrants and immigrants, participation of men is much higher than the proportion of women. It is therefore necessary to make the appropriate amendment on the basis of data on the distribution of emigrants and immigrants by gender. Otherwise there is a risk of exaggeration war losses by credit to the fallen in war those men who went abroad.

Secondly - the more casualties civilian population suffered in the war, the less is advisable to operate a female predominance. There is no doubt that if many wives and sisters of soldiers and officers died in the rear of hunger and diseases, epidemics, air raids and other reasons, the predominance of the number of women over the number of men will give the wrong idea about the actual number of fallen soldiers and officers. Predominance of women can give a real idea about the number of killed soldiers and officers only if the level of mortality among civilians is equal to the pre-war.

Thirdly - even if there was no war in certain age predominance groups, the number of women over the number of men would increase as a result of higher male mortality than women. It is known that in the formation of a number of men and women in all European countries is determined regularity consists in the fact that with increasing age, other things being equal, reduces the percentage of males. Therefore, the majority of women is also growing in conditions of peace. Therefore, in order to make the correct calculations must enter a patch. In relation to the above example, this means that if, for example before the war, majority of women expressed in the number of 300 thousand, after 10 years, it would increase in this age group to 400 thousand. Losses among the military would be, not $1500-1300=$ 200 thousand people, but $1500-400=1100$ thousand humans. Without taking into account this fact, that there is exaggeration of war losses among men. 
$5^{\text {th }}$ International Conference on Research in

While ignoring the first and third circumstance affects the exaggeration of the number of men killed in the war, ignoring other circumstances will determine the too low level. However, there is no reason to believe that the operation of the above circumstances offset each other. It is quite possible that ignoring other circumstances cause such errors, which are only slightly contribute to mitigating circumstances can ignore the first and third. Therefore, in each case should be carried out appropriate calculations on the basis of a whole range of statistics, except to offset the influence of the above mentioned circumstances. If the census was carried out quite late after the war, the use of data of women predomination, we should be aware that the inventory of this kind reflects not only the impact of the war, but also influence the effects of war.

It should also be noted that the censuses exist only in relation to the nineteenth and twentieth centuries. As regard to the determination of losses arising as a result of wars in the seventeenth and eighteenth centuries, the material of the census in this era do not exist. By studying this period in a number of cases we have to use the methods which fix certain proportion. Based on a number of specific factual data is calculated, eg. the ratio between the number of dead - on the one hand, and the number of dead as a result of diseases - on the other. Reported ratio, characteristic of the era, can later be used in other similar cases, in which there is no direct data. When determining the number of dead can be used repeatedly ratio between the number of killed and a number wounded. The loss data appear frequently overall number of dead and wounded. In these cases, knowledge of the correct ratio between the number of killed and wounded, can help determine the number of dead. A major help in determining the losses may be a method involving the use of the ratio calculated on the basis of data on losses among officers. With data on the ratio between the losses among the officers and losses among the soldiers, we can - on the basis of data on losses among the officers determine the total losses among soldiers and officers. Using the critically different sources, using the materials contained in the lists of the people and developing them using a largescale method for calculating the proportion and resorting to some extrapolation can be - at least approximately - determination the loss of life suffered by the armed forces during the war.

Terms of the war period are not conducive to obtaining full statistical information. In the villages occupied by the enemy often stops the current record of the natural movement of the population. As for the data on losses of war, and that they are often incomplete, random, which is connected with the course of the war. In addition, commanders often give false information about the losses of war, trying by all means minimize their losses and exaggerate enemy losses. Materials that can be considered more or less true, however also require conscientious checking and comparison. Only then the individual numbers can be use so that on the basis of the detached, isolated facts recreate the overall picture of the impact of war and lead to the determination of losses that it entails.

Sources of data on casualties during the war are diverse. First of all, official sources, which - with certain exceptions - can become the basis for calculations. Official data on 
$5^{\text {th }}$ International Conference on Research in

Behavioral and Social Science

Spain | Barcelona | December 7-9, 2018

casualties had in various periods different character. The first period covers the Middle Ages and beyond - until the beginning of the Thirty Years' War (to 1618). This era did not leave behind any reliable data on war casualties. Preserved only some data about the killed and wounded in the various major battles, the data raise serious doubts, because we do not have any documents, reports or notes from this period. The second period covers the time from the beginning of the Thirty Years' War to end War of the Spanish Succession (16181713). During this period, there are already the first reports preserved today and allows to evaluate not only the losses incurred in individual great battles, but also in smaller skirmishes, and in some cases, the information shall take into account the division of losses by types. Third period - from the end of the War of the Spanish Succession to the mid-nineteenth century (1713-1848). From this era have survived to our times opulent archives with different notes, reports, messages, lists, which in many cases contain accurate data on the size of the army and its changes as a result of various combat actions, including the number of dead, wounded, sick and prisoners. Sometimes the information includes not only individual battles, but the whole campaign. Preserved, for example data loss during the Napoleonic expedition to Egypt, and the losses of Wellington in Spain. There was, however, in this era of summary data about the whole war, any reports about the war. On the fourth period, covering more than 160 in recent years, there are already official data on not only individual battles and skirmishes, but the whole war.

From the point of view of the scope of the records of war losses, the evolution of the records can be characterized as follows: in the seventeenth and eighteenth centuries, keeping records fully only the losses among the generals, during the Napoleonic Wars - the officers, and only since the mid-nineteenth century, began carefully recording of losses among the rank and file. We have data on losses in World War I from the years 1914-1919, provided, however, that they involve all countries. In England and the United States even they published a multi-volume work of the official history of the war and provided with statistical material. In other countries, it is limited only to the publication of reports of the parliamentary committees. In a number of countries (eg. Russia, Germany, England) were published lists of persons killed, wounded and missing without a trace. However, in many countries there are no official data or publications. When calculating the losses of war, in addition to official data, great help may constitute semi-official sources. These should include the publishing of various institutions and organizations, published with the signatures of individuals. It should then indicate the work of historians wars. Some have developed materials for individual wars, other scholars undertake general studies concerning the wars in broad historical period. Particularly, one of the best is dictionary of battles, edited by the French statistics and historian Gaston Bodart ${ }^{14}$.

\footnotetext{
${ }^{14} \mathrm{G}$. Bodart, Losses of life in modern wars : Austria-Hungary : France, Oxford University Press, London 1916.
} 
$5^{\text {th }}$ International Conference on Research in Behavioral and Social Science Spain | Barcelona | December 7-9, 2018

\section{Bibliography}

1. Beebe G., Backey M., Battle Casualties, Springfield 1952.

2. Bodart G., Losses of life in modern wars : Austria-Hungary : France, Oxford University Press, London 1916.

3. Civilian death from air bombardment, Statistical Bulletin Metropolitan Life Ins. Co.

4. Farndon J., Historia świata: 2000 rzeczy, które musisz wiedzieć, Podsiedlik-Raniowski i Spółka, Poznań 2001.

5. Malthus T., Prawo ludności, De Agostini Poland, Warsaw 2003.

6. Malthus T., Prawo ludności, Jirafa Roja, Warsaw 2007.

7. Platon, Państwo, Warsaw 1948.

8. Sauvy A., Od Malthusa po Mao Tse-Tunga, Paris 1960.

9. Urłanis B., Wojny a zaludnienie Europy, Warsaw 1962.

10. Wyszczelski L., Teorie wojenne i ich twórcy na przestrzeni dziejów, Publisher Neriton, Warsaw 2009.

11. Zeitschrift des Königlich Preussischen Statistischen Landesamts, volume 11, number 1-4. 